\title{
DSCLAIMIXR
}

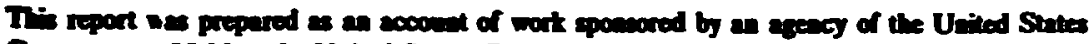

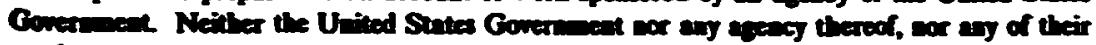

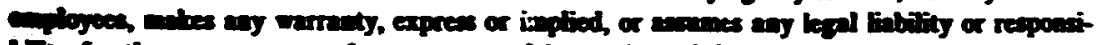

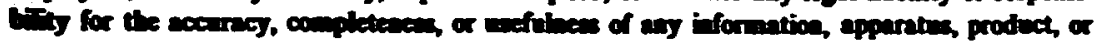

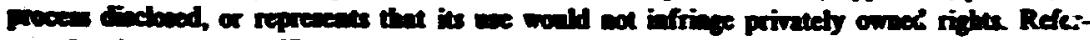

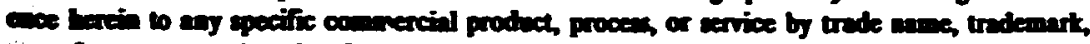

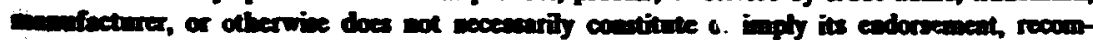

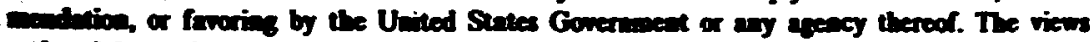

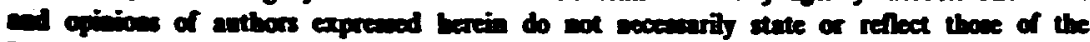

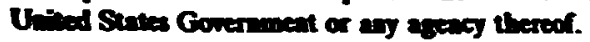

\author{
ORNL/FEDC-83/2 \\ Dist. Category UC-20 c, d
}

Fusion Energy Division

OR:LL/FEDC- $-83 / 2$

DERS CO2151

\section{NUMERICAL SIMULATION OF THE PLASMA CURRENT QUENCH FOLLOWING A DISRUPTIVE ENERGY LOSS}

D. J. Strickler, Computer Science Division

Y-K. M. Peng, Fusion Energy Division

J. A. Holmes, Computer Science Division

J. B. Miller, The University of Tennessee

K. E. Rothe, Computer Science Division

NoTice This document contains informotion of a preliminary nature. It is subject to revision or correction and therefore does not represent a tinal report.

Date Published - November 1983

Prepared by the

OAK RIDGE NATIONAL LABORATORY

Oak Ridge, Tennessee 37830 operated by

UNION CARBIDE CORPORATION

for the

I:.S. DEPARTMENT OF ENERGY

under Contract No. W-7405-eng-26 


\section{CONTENTS}

ACKNONLEDGENTS $\ldots \ldots \ldots \ldots \ldots \ldots \ldots \ldots \ldots \ldots \ldots \ldots \ldots \ldots \ldots \ldots \ldots$ iv ABSTRACT $\ldots \ldots \ldots \ldots \ldots \ldots \ldots \ldots \ldots \ldots \ldots \ldots \ldots \ldots \ldots \ldots \ldots \ldots \ldots \ldots \ldots$

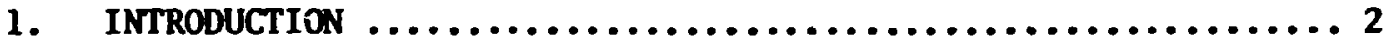

2. EQUATIONS $\ldots \ldots \ldots \ldots \ldots \ldots \ldots \ldots \ldots \ldots \ldots \ldots \ldots \ldots \ldots \ldots \ldots \ldots$

3. METHOD of SOLUTION $\ldots \ldots \ldots \ldots \ldots \ldots \ldots \ldots \ldots \ldots \ldots \ldots \ldots \ldots \ldots$

4. $\quad$ RESULTS $\ldots \ldots \ldots \ldots \ldots \ldots \ldots \ldots \ldots \ldots \ldots \ldots \ldots \ldots \ldots \ldots \ldots \ldots \ldots$

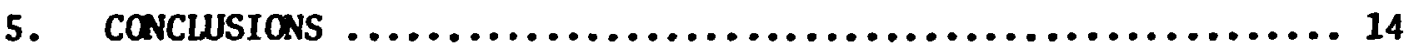

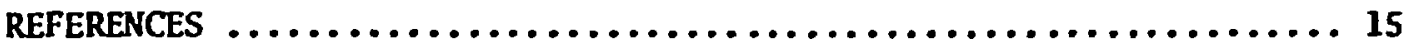




\section{ACKNONLEDGMENTS}

The authors are grateful to Melinda Corer for her careful preparation of the document and to P. W. Gaffney for his assistance in obtaining the appropriate numerical software for this study. 


\section{ABSTRACT}

The plasma electromagnetic interaction with poloidal field coils and nearby passive conductor loops during the current quench following a disruptive loss of plasma energy is simulated. By solving a differential/algebraic system consisting of a set of circuit equations (including the plasma circuit) coupled to a plasma energy balance equation and an equilibrium condition, the electromagnetic $c$ isequences of an abrupt thermal quench are observed. Limiters on the small and large major radius sides of the plasma are assumed to define the plasma cross section. The presence of good conductors near the plasma and a small initial distance (i.e., 5-10\% of the plasma minor radius) between the plasma edge and an inboard limiter are shown to lead to long current decay times. For a plasma with an initial major radius $R_{0}=4.3 \mathrm{~m}$, aspect ratio $A=3.6$, and current $I_{p}=4.0 \mathrm{MA}$, introducing nearby passive conductors lengthens the current decay from milliseconds to hundreds of milliseconds. 


\section{INTRODUCTION}

Disruptions in tokamak plasmas are generaliy assumed to result from growing tearing modes, leading to magne ic island overlap and enhanced heat conduction. ${ }^{1}$ This is usually followed by a loss of plasma position and current through electromagnetic effects and catastrophic interaction with limiters. These two phases may be termed as the thermal quench and current quench, respe:tively. A model has been developed to explore the basic plasma e ectrumagnetic phenomer'on associated with the second phase, that is, the curcent decay following a plasma disruptive thermal quench.

If the current quench can be presented in tokamaks, ic may be possible to restore plasma confinement w.thout machine shutdor.h. The ASLEX tokamak ${ }^{2}$ (with a vacuurn vessel time constant of $10 \mathrm{~ms}$ and efficient feedback on plasma current, position, and density) has denonstrated recovery from sequences of therrial quenct and has successfully avoided the usually fast current quench.

Present torus designs are typically infilueı.ced by inductive startup requirements and need a relatively high electrical resisiance vacuum vessel. Long pulse $t:$ mes in fut: $x \in$ reactors may permit long startup scenarios and hence lower resistance stmuctures near the plasma. Previous electroraznetic stucies on tice Fusion Engineering; Device $(F E D)^{3}$ suggest that gcod passive conductors near the plasma increase the current decay phase, prutzcting firsc wall surfaces frcm the effects of a disruption. Results reported in the FED-A study ${ }^{4}$ suggest that a closely fitted $\sim 1-\mathrm{cm}$-thick copper sheli at a radius of 1.1-1.4 times the plasma minor radius would be effective in actually preventing disruptions in low 4 discharges by liriring the growth tine of tearing modes. The avoidance of disruption or the recovery of confinement following a disruption is of great imprortence in future tonkarak devices where the large thermal and magnetic stored eltergy would porentially damage the machii 3 . A first step in this dire.tion is to obtain quantitative estimates of the effects of nearby conductors slowing the rate of the current quench. 
The plasma electromegnetic inter. tion with its environment, including poloidal field coils, rearb: passive conductors (e.g., a conducting first wallj, and Jimiters, is des:ribed by circuit equations, a simplified energy balance, and an equilibriuf relationsinip. The resulting system, including bot: difficential and algebraic equations, is solved by efficient computational methods using state-of-the-art software. 


\section{EQUATIONS}

The mod 1 assumes toroidal symmetry and a circular plasma cross section with the plasma size a determined by the relative position of the plasma major radius $R_{p}$ with respect to the limiter location $R_{L}$ :

$$
a_{p}= \begin{cases}R_{p}-R_{L} & R_{P}<R_{L}+a_{c} \\ a_{c} & R_{L}+a_{c}<R_{p}<R_{R}-a_{c} \\ R_{R}-R_{P} & R_{r}=R_{R}-a_{c}\end{cases}
$$

where $a_{c}$ is the initial plasma minor radius. That is, when the plasma position $R_{p}, Z_{p}$ is such that the cross section intersects a limiter, the minor rildius a is reduced linearly.

Circuit equations for the conduct or currents $\left(I_{i}, i=1, \ldots, N\right)$ and plasma current $\left(I_{p}\right)$ are

$$
\begin{aligned}
& \sum_{\substack{j \neq 1 \\
j \neq i}}^{N} M_{i j} \dot{I}_{j}+L_{i} \dot{I}_{i}+M_{i p} \dot{I}_{p}+I_{p} \frac{\partial M_{i p}}{\partial R_{p}} \dot{R}_{F}+I_{p} \frac{\partial M_{i p}}{\partial Z_{p}} \dot{z}_{p}=V_{i}-\Omega_{i} I_{i}, \\
& \sum_{j=1}^{N} M_{p j} \dot{I}_{j}+L_{p} \dot{I}_{p}+\left(I_{p} \frac{\partial L_{F}}{\partial R_{p}}+\sum_{j=1}^{N} I_{j} \frac{\partial M_{p j}}{\partial R_{p}}\right) \dot{R}_{p} \\
& +\sum_{j=1}^{N} I_{j} \frac{\partial M_{p j}}{\partial Z_{p}} \dot{z}_{p}=-\Omega_{p} I_{p},
\end{aligned}
$$

where the resistances $\Omega_{i}$, voltages $v_{i}$, and self and mutual inductances $L_{i}, M_{i j}$ are given. The inductances $M_{p j}$ and $L_{p}$ depend on the plasma position and minor radius through $\mathrm{Eq}$. (1). Inductances are computed by the methods described in Ref. 5. The plasma resistance, also influenced by Eq. ( 1 ), is given by 


$$
\begin{aligned}
& \Omega_{p}=3.276 \times 10^{-9} \frac{Z_{\text {eff }} \ln \Lambda R_{p}}{a_{p}{ }^{2} T_{e}^{3 / 2}}, \\
& T_{e}=\frac{2}{3} \frac{H_{p}}{v_{p}{ }_{e}^{k}}, \\
& \text { In } \Lambda=37.82-\ln \left(\frac{n_{e} e^{1 / 2}}{T_{e}}\right),
\end{aligned}
$$

where $z_{\text {eff }}, n_{e}$ (electron density) are input and $v_{p}$ is the plasma volume. A simplified energy balance for the total plaswa energy $w_{p}$ is given by

$$
\dot{w}_{p}=-\frac{w_{p}}{\tau_{E}}+\Omega_{p} I_{p}{ }^{2},
$$

where the energy confinement time is assumed to be

$$
\tau_{E}=\frac{\lambda}{2} n_{c} a_{p}^{2} \times 10^{-20}
$$

A scale factor $\lambda$ in Eq. (6) is used to simulate the magnitude of the thermal quench; that is, it serves to arbitrarily decrease the plasma energy confinement time so the plasma energy will rapidly decrease and the electromagnetic consequences may be observed.

Plasma movement is assumed to take place on the magnetohydrodynamic (MD) time scale, governed by the equilibrium conditions

$$
\begin{aligned}
& \sum_{j=1}^{N} B_{Z}\left(R_{p}, Z_{p}, R_{j}, z_{j}\right) I_{j}=B_{v}\left(R_{p}, a_{p}, I_{p}, w_{p}\right), \\
& \sum_{j=1}^{N} B_{R}\left(R_{p}, Z_{p}, R_{j}, z_{j}\right) I_{j}=0,
\end{aligned}
$$


where the required externally applied vertical field for MAD equilibrium is given by the Shafranov formula: ${ }^{6}$

$$
B_{R}=\frac{\mu I p}{4 \pi R_{p}}\left(\ln \frac{8 R_{p}}{a_{p}}+B_{p}-\frac{\ell_{i}}{2}-1\right) \text {, }
$$

where

$$
\beta_{p}=\frac{8}{3 \mu}\left(\frac{w_{p}}{R_{p} I_{p}^{2}}\right)
$$

and the plasma internal inductance for a uniform current distribution is $\ell_{i}=1 / 2$. The functions $B_{L}$ and $B_{R}$ give the vertical and radial components, respectively, of the poloidal magnetic ficld at $R_{p}, Z_{p}$ due to unit currenis in conductors located at $R_{j}, z_{j}$. Specifically, $B_{2}=k\left(R_{p} R_{j}\right)^{-1 / 2}\left[K\left(k^{2}\right)+\frac{R_{j}{ }^{2}-R_{p}^{2}-\left(z_{p}-z_{j}\right)^{2}}{\left(R_{j}-R_{p}\right)^{2}+\left(z_{p}-z_{j}\right)^{2}} E\left(k^{2}\right)\right]$,

$B_{R}=k\left(z_{p}-z_{j}\right)^{2}\left(\frac{R_{p}}{R_{j}}\right)^{1 / 2}\left[-K\left(k^{2}\right)+\frac{R_{j}^{2}+R_{p}^{2}+\left(z_{p}-z_{j}\right)^{2}}{\left(R_{j}-R_{p}\right)^{2}+\left(z_{p}-z_{j}\right)^{2}} E\left(k^{2}\right)\right]$

where $k^{2}=4 R_{p} R_{j} /\left[\left(R_{p}+R_{j}\right)^{2}+\left(z_{p}-z_{j}\right)^{2}\right]$ and $K$ and $E$ are elliptic integrals of the first and second kind, respectively.

A further assumption in the present model is that the plasma does not experience the magnetic effect of those coils designated as ohmic heating coils. That is, these coils are inductively linked to the plasma through the circuit equations but do not appear in the calculation of the vertical field at the plasma. Physically, this assumption would be accurate in the case of a decoupled roloidal field system in which trim coils cancel the field of the ohmic heating solenoid at the plasma. 


\section{METHOD OF SOLUTION}

Equations similar to Eqs. (2), (3), and (7)-(9) have been used to simulate feedback control of plasma position and current in tokamaks. The typical method of solution is to take the time derivative of the equilibrium expressions (6)-(8) and solve the resulting system as a set of ordinary differential equations (ODEs), given a sez of initial values of the dependent variables. The approach used ir this study is to treat these equations in their present form, making use of currently available numerical software for solving differential/algebraic equations (DAEs). ${ }^{-}$This was necessary to accurately include the limiter model [Eq. (1)] since it is a nondifferentiable function. More specifically, Eqs. (1)-(8) are written in the for 1

$$
F(t, y, \dot{y})=A(t, y) \dot{y}-b(t, y)=0,
$$

where

$$
y=\left(I_{1}, \ldots, I_{N}, I_{p}, w_{p}, R_{p}, z_{p}\right)^{t}
$$

Two software packages, LSODI and DASSL, hase been used to solve this system of equations. LOODI ${ }^{9}$ was written by A. C. Hindmarsh and J. F. Painter to solve stiff or nonstiff initial value ODEs in the linearly implicit form $A(t, y) \dot{y}=b(t, y)$, where $A$ is a square matrix. This code has the option, however, of solving DAEs of the same form (i.e., where $A$ is singular) if initial values of the derivati: ?s $\dot{y}_{0}$, as well as function values $y_{0}$, of the dependent variables are supplied (at $t_{0}$ ). The initial derivative vector is required to be consistent with $t_{0}$ and $y_{0}$ in the sense that $A\left(t_{0}, y_{0}\right) y_{0}=b\left(t_{0}, y_{0}\right)$.

DASSL $^{10}$ was written specifically to solve DAE systems of a general form $F(t, y, \dot{y})=0$, given the appropriate initial values. DASSL has an option available for approximately $\dot{y}_{0}$ at the expense of mcre function evaluations.

Both codes use methods designed for stiff systems of ODEs based on replacing derivatives with backward differentiation formulas and 
solving a resulting set of nonlinear equations using a variation of Newton's method. That is, LSODI solves the set of nonlinear equations

$$
F\left(t_{n}, y_{n}, \frac{y_{n}-y_{n-1}}{\Delta t_{n}}\right)=0
$$

for the value of the vector $y_{n}$ at $t_{n}$. Where LSODI uses the first-order formula (13), DASSL approximates the derivative with backward differentiation formulas of orders one through five, choosing the order as well as the step size $\Delta t_{n}$, depending on the behavior of the solution. In the solution of Eqs. (1)-(8), an initial derivative vector is obtained by replacing the equilibrium equations in the system with their derivatives to obtain $\tilde{A} y_{0}=\tilde{b}$ and then solving for $y_{0}$. The matrix $\tilde{A}$ and vector $\tilde{b}$ are given by

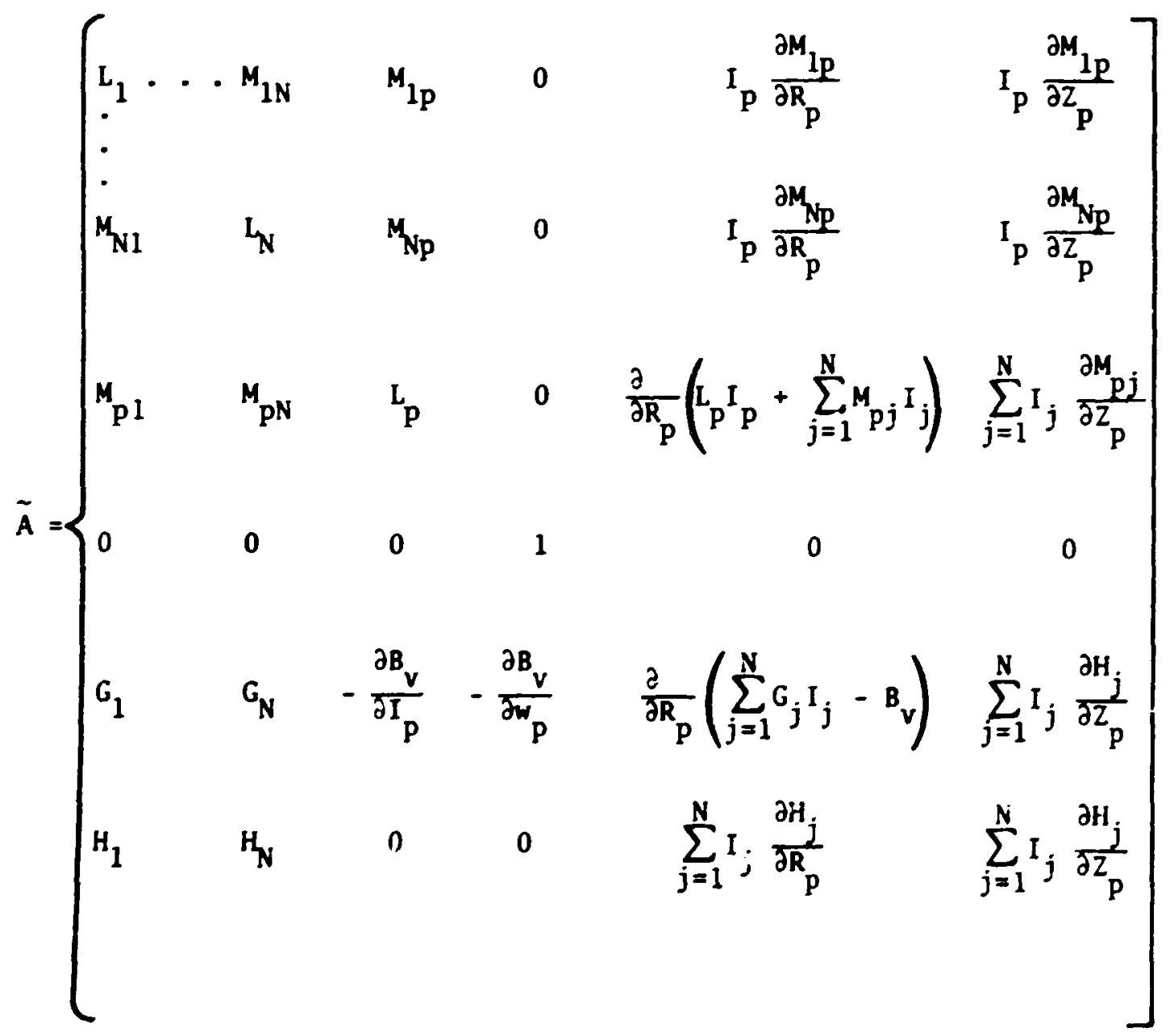


$\tilde{b}=\left(\begin{array}{c}v_{1}-\Omega_{1} I_{1} \\ \dot{v_{N}}-\delta_{N_{N}} I_{N} \\ -\Omega_{p} I_{p} \\ -w_{p} / \tau_{E} \cdot \Omega_{p} I_{p}^{2} \\ 0 \\ 0\end{array}\right)$

Given similar error criteria, the two coles produced virtually the same solutions to test problems based on this particular set of equations. DASSL, however, used somewhat fewer matrix evaluations and less computer time ${ }^{11}$ and was adopted for use in generating the results of this study.

A typical configuration and set of solution curves are shown in Figs. 1 and 2. Initial plasma parameters for this case are summarized in Tabie 1. The poloidal field coil system consists of ohnic heating (Gi) coils, equilibrium field (EF) coils, and passive conductors near the plasma. Coil locations, currents, and resistivities are given in Table 2. The inboard limiter position is $R_{L}=3.1 \mathrm{~m}$.

Simulating the effect of the thermal phase of a disruption by setting $\lambda=0.005$, thore is a sharp dacrease in the plasma enezgy over the first $12-15 \mathrm{~ms}$. During this time, there is a $35-\mathrm{cm}$ decrease in major radius and a 600-kA reduction in plasma current [Fig. 2(a)] as eddy currents [Fig. 2(b)] are being induced to oppose these changes. This initial phase is followed by a 200-ms interval during which current and plasma position decrease linearly. Finally, there is evidence of a total plasma current quench shortly after $212 \mathrm{~ms}$, although. DASSL reaches a point where it cannot sacisfy the given error criteria as $a_{p} \rightarrow 0$. 
Table 1. Initial plasma parameters

\begin{tabular}{lccc}
\hline & Symbol & Units & Value \\
\hline Major radius & $\mathrm{R}_{\mathrm{p}}$ & $\mathrm{m}$ & 4.3 \\
Minor radius & $\mathrm{a}_{\mathrm{p}}$ & $\mathrm{m}$ & 1.2 \\
Plasma current & $\mathrm{I}_{\mathrm{p}}$ & $\mathrm{MA}$ & 4.0 \\
PJasma temperature & $\mathrm{T}_{\mathrm{e}}$ & $\mathrm{keV}$ & 10.0 \\
Vertical field & $\mathrm{B}_{\mathrm{v}}$ & $\mathrm{T}$ & 0.28 \\
\hline
\end{tabular}

Table 2. Locations and size of conductor

\begin{tabular}{ccccccc}
\hline $\mathrm{R}(\mathrm{m})$ & $Z(\mathrm{~m})$ & $\mathrm{a}(\mathrm{m})$ & $\mathrm{b}(\mathrm{m})$ & $\mathrm{I}(\mathrm{MA})$ & $\rho(\Omega-\mathrm{m})$ & Type \\
\hline 9.5 & \pm 4.0 & 0.4 & 0.4 & 2.67 & 0.01 & $\mathrm{EF}$ \\
1.2 & \pm 1.0 & 0.4 & 1.0 & 10.0 & 0.01 & $\mathrm{OH}$ \\
2.8 & 0.0 & 0.1 & 0.1 & 0.0 & 20.0 & \\
5.8 & 0.0 & 0.1 & 0.1 & 0.0 & 2.0 & passive \\
4.3 & 1.5 & 0.1 & 0.1 & 0.0 & 20.0 & conductors \\
4.3 & -1.5 & 0.1 & 0.1 & 0.0 & 2.0 & \\
\hline
\end{tabular}




\section{RESULTS}

For the same initial plasma parameters, EF, and $\mathrm{OH}$ coils as in Tables 1 and 2 but with no passive conductors, the duration of the current quench decreases as $\lambda$ is reduced. Here, $\lambda$ is a scale factor in the equation for the energy confinement time, defined in Eq. (6), controlling the rate of the plasma energy quench. Assuming the plasma is initially in contact with the inboard limiter, the effect of changing $\lambda$ from 0.001 to 0.015 is to exiend the current quench time from less than 1 ms to $9 \mathrm{~ms}$, as shown in Fig. 3.

Passive conductors near the plasma, such as a conducting first wa11, have the effect of delaying the current quench following a disruption through the induction of eddy currents in a direction such that the rate of current decrease is opposed. The current decay then depends on the position and resistance of the conducting elements. The effect of conductor resistivity $\rho$ is shown by including the passive conductors of Table 2 with uniform resistivity (but differing in resistance due to their position) and obtaining solutions for various values of $\rho$. Again, the initial plasma is in contact with an inboard limiter, and the disruption is simulated by a value of $\lambda=0.005$. Figure 4 shows the current decay curves for $\rho>1.6 \Omega-\mathrm{m}$. For $\rho=1.6 \Omega-\mathrm{m}$, the plasma current decay that occurred in $3 \mathrm{~ms}$ with no passive conductors near the plasma is extended to greater than $140 \mathrm{~ms}$.

The impact of varying the inboard limiter radial position $R_{L}$ in the plasma/limiter interaction model [Eq. (1)] is shown in Fig. 5. with some nonzero distance between the initial plasma and the inboard limiter, the plasma current tends to increase prior to contact with the limiter. During this time, the minor radius remains constant, but the energy loss causes a decrease in the aspect ratio, i.e., a compression of the plasma column. As shown in Fig. 5, where $\lambda=0.005$, this initial distance between the plasma and limiter extends the current quench time.

By moving the passive conductors closer to the plasma, the mutual coupling is improved, and the resistance in the outboard conductors lowered, resulting in a longer plasina current decay time. Characterizing the constant distance from the plasma center to the passive 
conductors of Table 2 by $a_{w}$, the effect of decreasing $a_{w}$ is shown in Fig. 6. Here, $\lambda=0.005$ and there is 1 nitially a $10-\mathrm{cm}$ distance between the initial plasma edge and the inboard limiter. As shown in Fig. 6, a 60-cm decrease in a implies a greater than $30 \%$ increase in the current quench time.

Conductors near the plasma on the outboard side are important in extending the current decay. In Fig. 7, a configuration with the same plasma initial conditions and passive conductors as used in Tables 1 and 2 , but with $\rho=1.6 \times 10^{-6} s_{i}-m$ in the passive conductors, is compared to configurations with the inboard and outboard conductors omitted. The configuration including the outboard passive conductor is clearly the most effective in slowing the current quench, and the configuration without an outboard conductor is least effective.

Figure 8 shows the effect of poloidal asymmetry in the passive conductors by omitting the upper conductor $(R=4.3 \mathrm{~m}, Z=1.5 \mathrm{~m})$ from the configuration of Table 2. With the same disruption condition $(\lambda=0.005)$, the initial plasma movement is inward due to the decrease in $\beta_{p}$, but eddy currents in the same direction as the plasma current induced in the passive conductor below the midplane also cause a downward motion. Finally, as the plasma current decays, the larger induced current in the inboard conductor has an attractive effect, and the direction of plasma motion is toward the midplane.

In a further application, it was observed that in a smaller plasma of lower temperature $\left(R_{p}=1.0 \mathrm{~m}, a_{p}=0.2 \mathrm{~m}, I_{p}=0.2 \mathrm{MA}, \mathrm{T}_{e}=1 \mathrm{keV}\right.$, $\lambda=0.01$ ), a set of conductor initial conditions could be for nd (Table 3) such that the plasma current would decay with no change in minor radius through limiter interaction. That is, with a $10-\mathrm{cm}$ distance between the limiter and the initial inboard edge of the plasma, a current quench ( $\sim 7 \mathrm{~ms}$ ) takes place on essentially the $L / R$ time of the plasma. Here the plasma column first moves inward, although not enough to contact the limiter, and then begins moving outward toward the end of the simulation (Fig. 9). This result indicates the possibility of a low beta plasma quenching under certain conditions in the center or outboard side of the ci.amber. 
Table 3. Conductor locations for simulatisn of Fig. 9

\begin{tabular}{lccccc}
\hline$R(\mathrm{~m})$ & $Z(\mathrm{~m})$ & $\mathrm{a}(\mathrm{m})$ & $b(\mathrm{~m})$ & $I(\mathrm{kA})$ & $\rho\left(s_{l}-\mathrm{m}\right)$ \\
\hline 1.50 & \pm 0.15 & 0.05 & 0.05 & 43.0 & 2.0 \\
0.25 & \pm 0.15 & 0.05 & 0.10 & 100.0 & 2.0 \\
0.65 & \pm 0.15 & 0.03 & 0.03 & 0.0 & 150.0 \\
1.35 & \pm 0.15 & 0.03 & 0.03 & 0.0 & 2.0 \\
\hline
\end{tabular}




\section{CONCLUSIONS}

The electromagnetic impact of a plasma major disruption on the components of a tokamak device is strongly related to the eddy current time constants of conductors near the plasma. Passive conductors, such as a highly conducting first wall, can greatly extend the current decay time. The presence of good passive conductors in torus designs would also influence the plasma inductive startup requirements, but the possibility of long startup and pulse times in future reactors may make such designs appear feasible.

In this work, the electromagnetic consequences of a disruptive energy losj are modelled with a difíerential/algebraic system of equations that includes circuit equations for the plasma and conductors, an energy balance equation, an equi ibrium condition determining the plasma position, and an assumed plasma/limiter relationship defining the size of the plasma as a function of time. Results indicate that the current decay time following a disruptive loss of plasma energy can be extended by factors of 10 tc $10^{2}$ by (1) pusitioning passive conductors (e.g., a conducting first wall) near the plasma; (2) extending the time constant of these conductors; and (3) detaching the plasma from an inboard limiter (e.g., with a poloidal divertor). The study shows that conductors on the outboard side of the plasma are most effective in slowing the current quench. 
REFERENCES

1. B. Carreras, H. R. Hicks, J. A. Holmes, and B. V. Waddell, Phys. Fluids 23, 1811 (1980).

2. F. Schneider, "Operation of the ASDEX Feedback System," in Proceedings of the 11th Symposium on Fusion Technology, Oxford (1980), p. 1027 .

3. J. G. Murray and G. Bronner, Disruption Model, PPPL-1909, Princeton Plasma Physics Lab., Prínceton, N.J., 1982.

4. Y-K. M. Peng et al., FED-A, An Advanced Performance FED Based on Low Safety Factor and Current Drive, ORNL/FEDC-83/1, 0ak Ridge Nat:. Lab., Fusion Engineering Design Center, 1983.

5. M. W. Garrett, Journ. App 1. Phys. $\underline{34}, 9$ (1963).

6. V. S. Mukovatov and V. D. Shafranov, Nucl. Fusion 11, 605 (1971).

7. L. A. Charlton, D. W. Swain, and G. H. Neilson, IEEE Trans. Plasma Science PS-7 (4) (December 1979).

8. L. Petzold, SIAk: J. Sci. Stat. Comput. $\underline{3}$ (3), 36- (1982).

9. A. C. Hindmarsh, "Stiff System Problems and Soluticns at LLNL," presented at the International Conference on Stiff Computation, Park City, Utah (1982) UCRL-87406.

10. L. R. Petzold, DASSL: A Differential/Algebraic System Solver, SAND 82-8637, Sandia Nat'l. Lab., Livermore, CA, 1982.

11. D. J. Strickler, Y-K. M. Peng, K. E. Rothe, P. W. Gaffney, J. B. Miller, "Treating a Plasma Electromagnetics Problem as a System of Differential/Algebraic Equations," in Proceedings of the 10th Conference on Numerical Simulation of Plasmas, San Diego (to be published). 


\section{FIGURE CAPTIONS}

Fig. 1. Initial plasea size and conductor geometry. The dashed lines are contours of constant poloidal flux created by the EF coils and passive conductors.

Fig. 2(a). Typical solution curves showing the time dependent behavior of the plasma current $I_{F}$, major radius $R_{P}$, vertical position $Z_{p}$, and plasma energy $w_{p}$. Also included are the plasma ninor radius $a_{p}$ and equilibrium vertical field $B_{v}$.

Fig. 2(b). Typical solution curres showing the time dependent behavior of the passive conductor currents.

Fig. 3. Plasma current quench, in a configuration with no passive conductors, for various values of $\lambda$.

Fig. 4. Plasma current quench for various values of passive conductor resistivity $\rho(\Omega-m)$.

Fig. 5(a). As the major radius decreases, the plasma current increases prior to contact with the limiter, as sho..n here for various limiter positions $R_{L}$.

Fig. 5(b). Plasma current quench for various limiter positions.

Fig. 6. Plasma current quench for different distances between plasma and passive conductors $a_{w^{*}}$

Fig. 7. Current quench for different passive conductor configurations.

Fig. 8. Plasma position and size relative to conductors at various times during the current quench in an asymetric configuration.

Fig. 9. Solution curves for major radius, vertical field, and plasma current in a simulation with no limiter contact (no change in minor radius). 


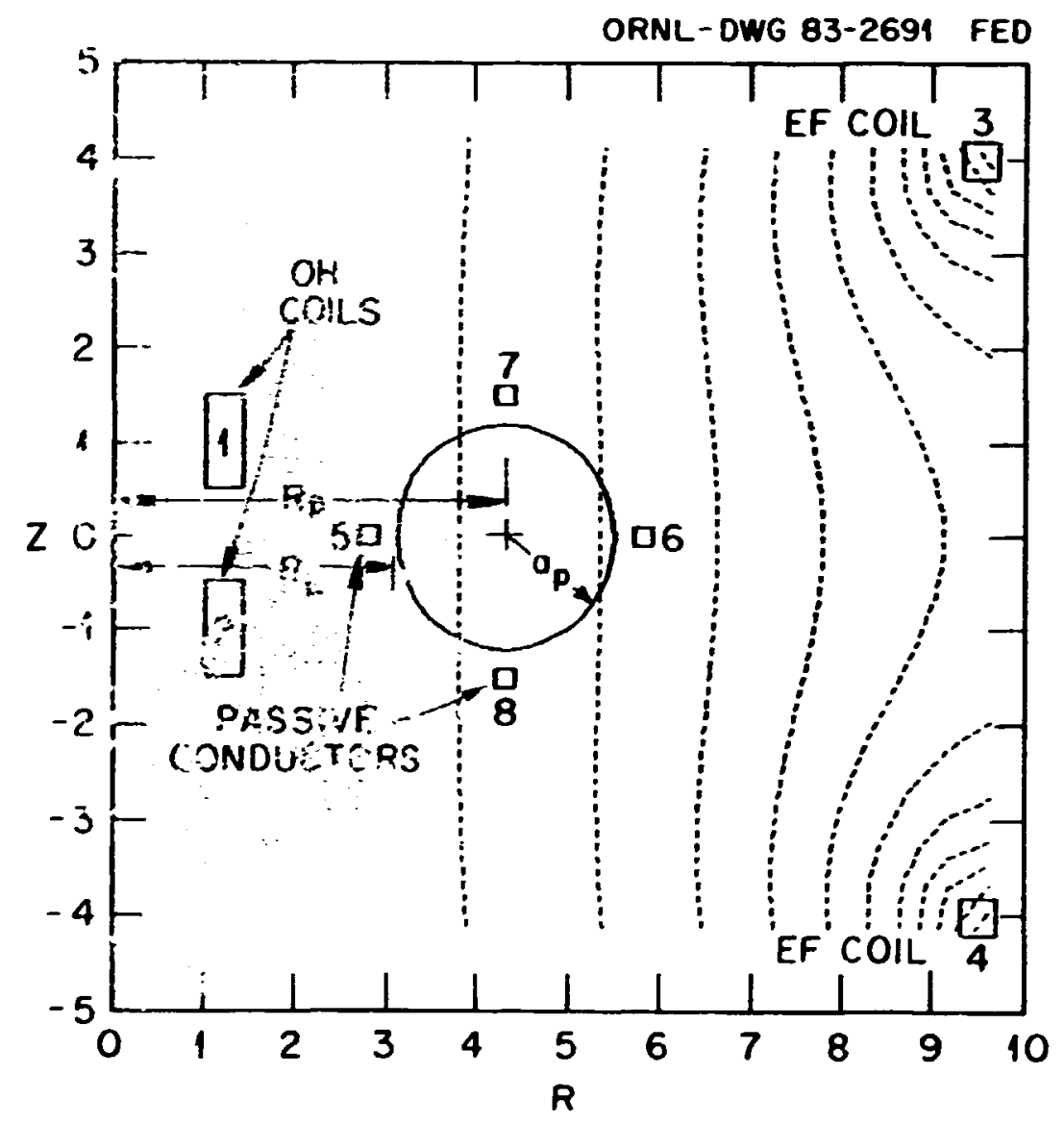

Fig. 1 


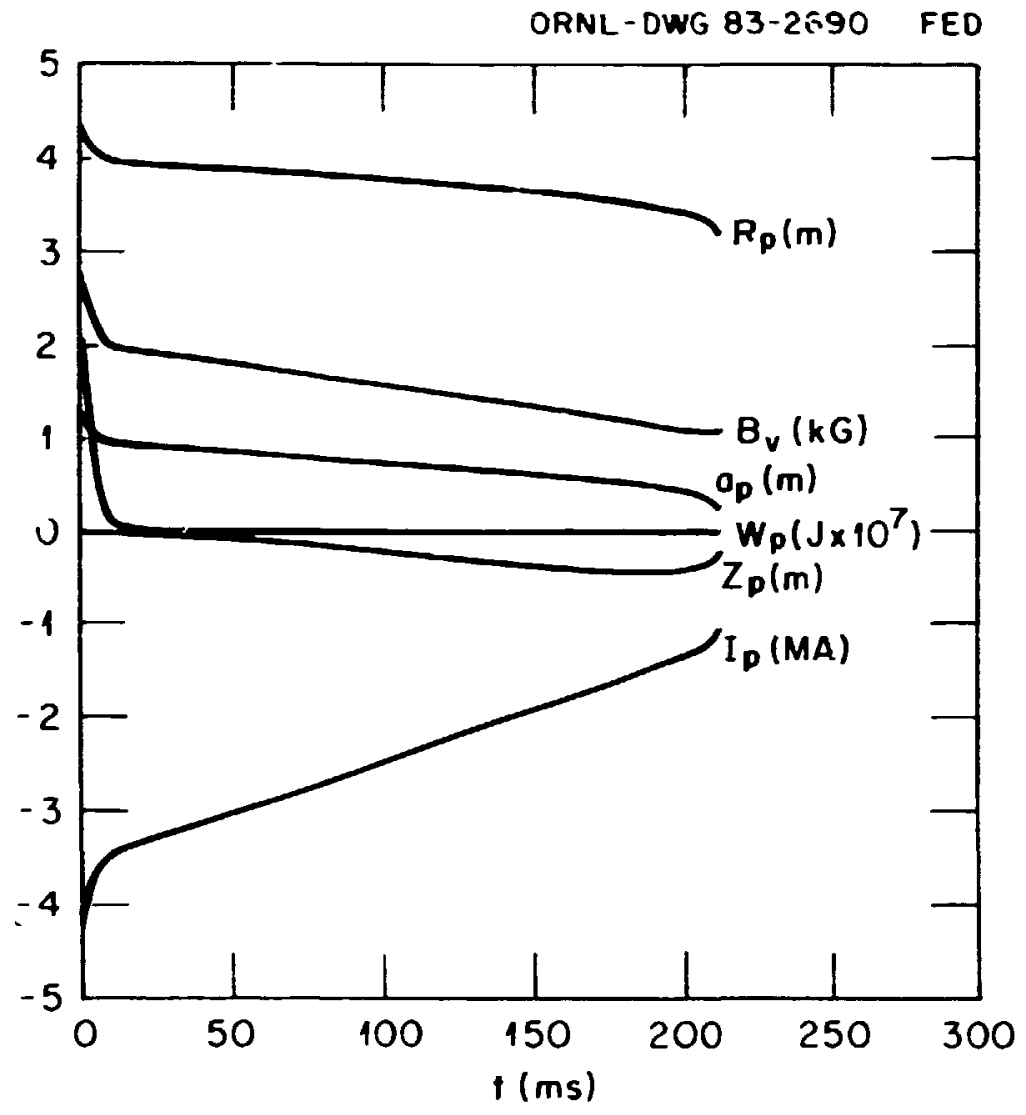

Fig. 2(a) 


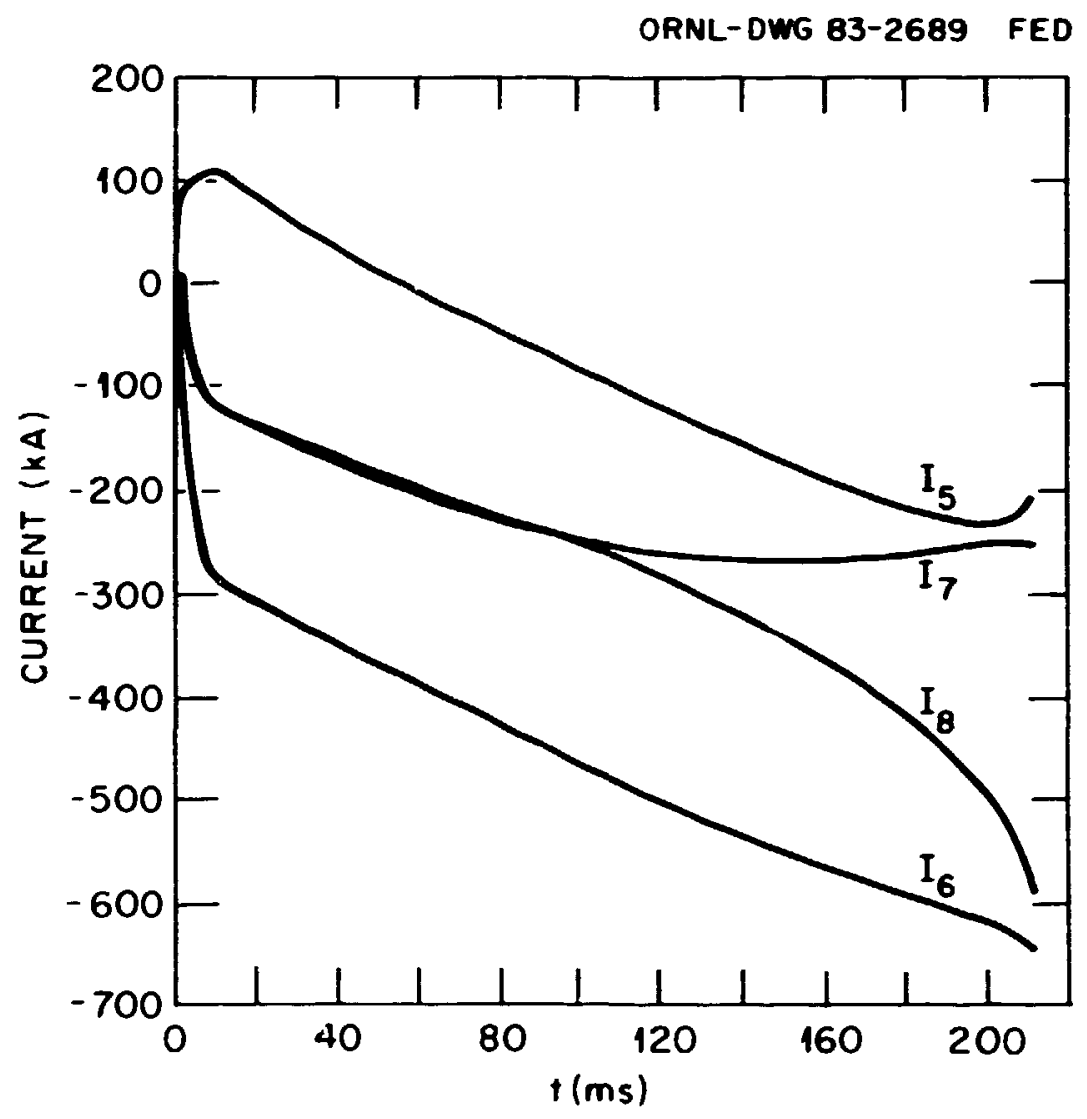

Fig. 2(b) 


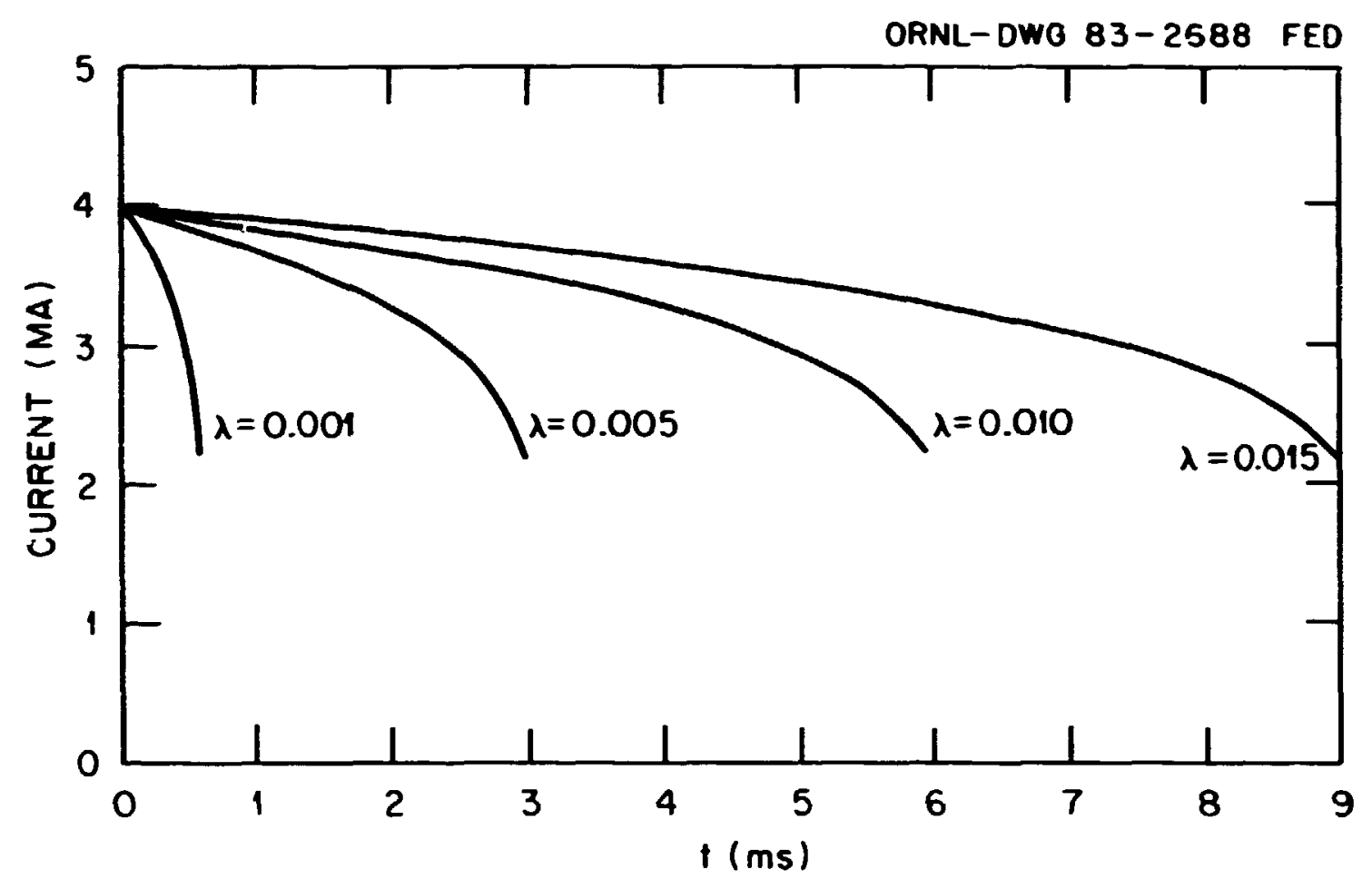

Fig. 3 


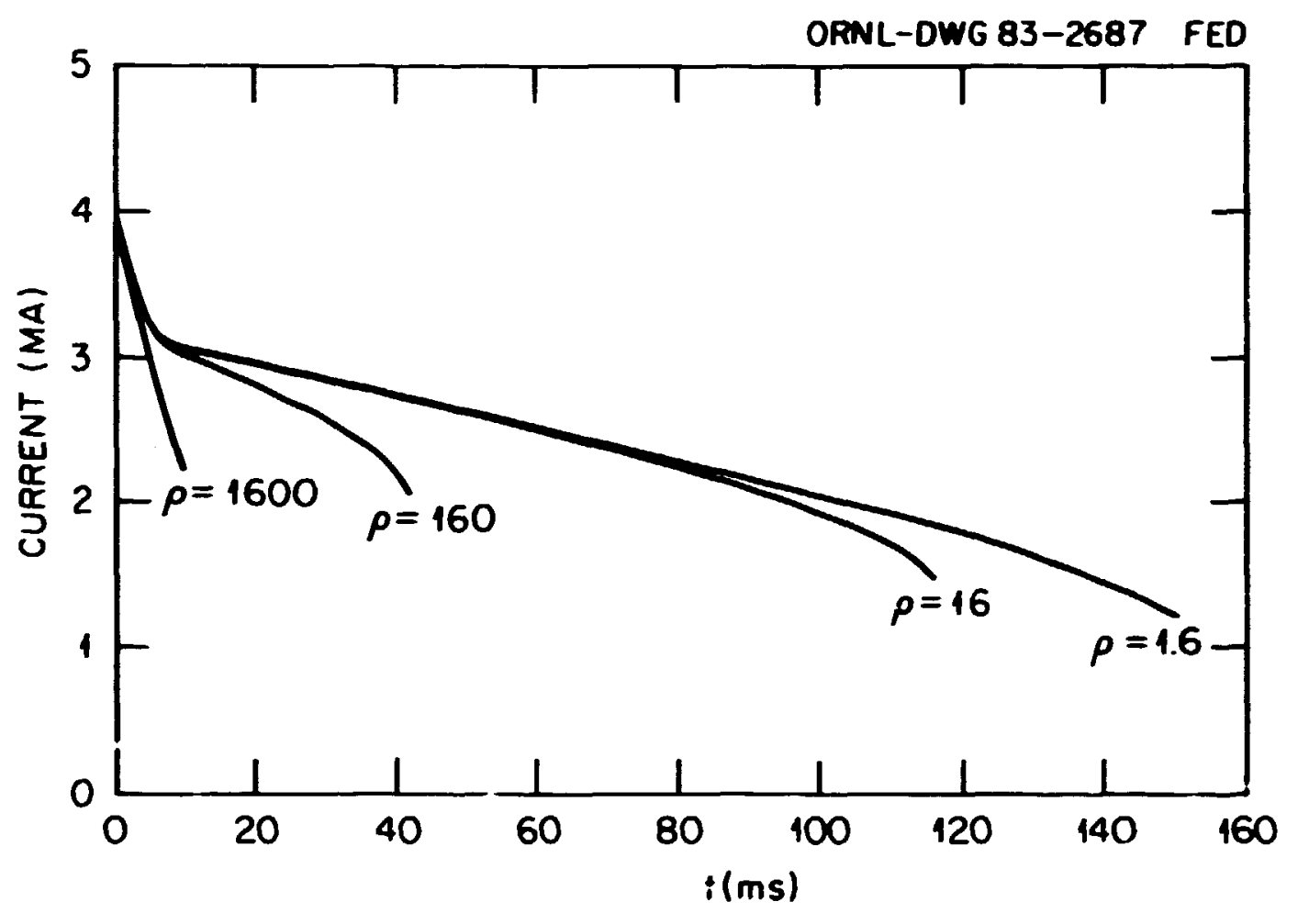

Fig. 4 


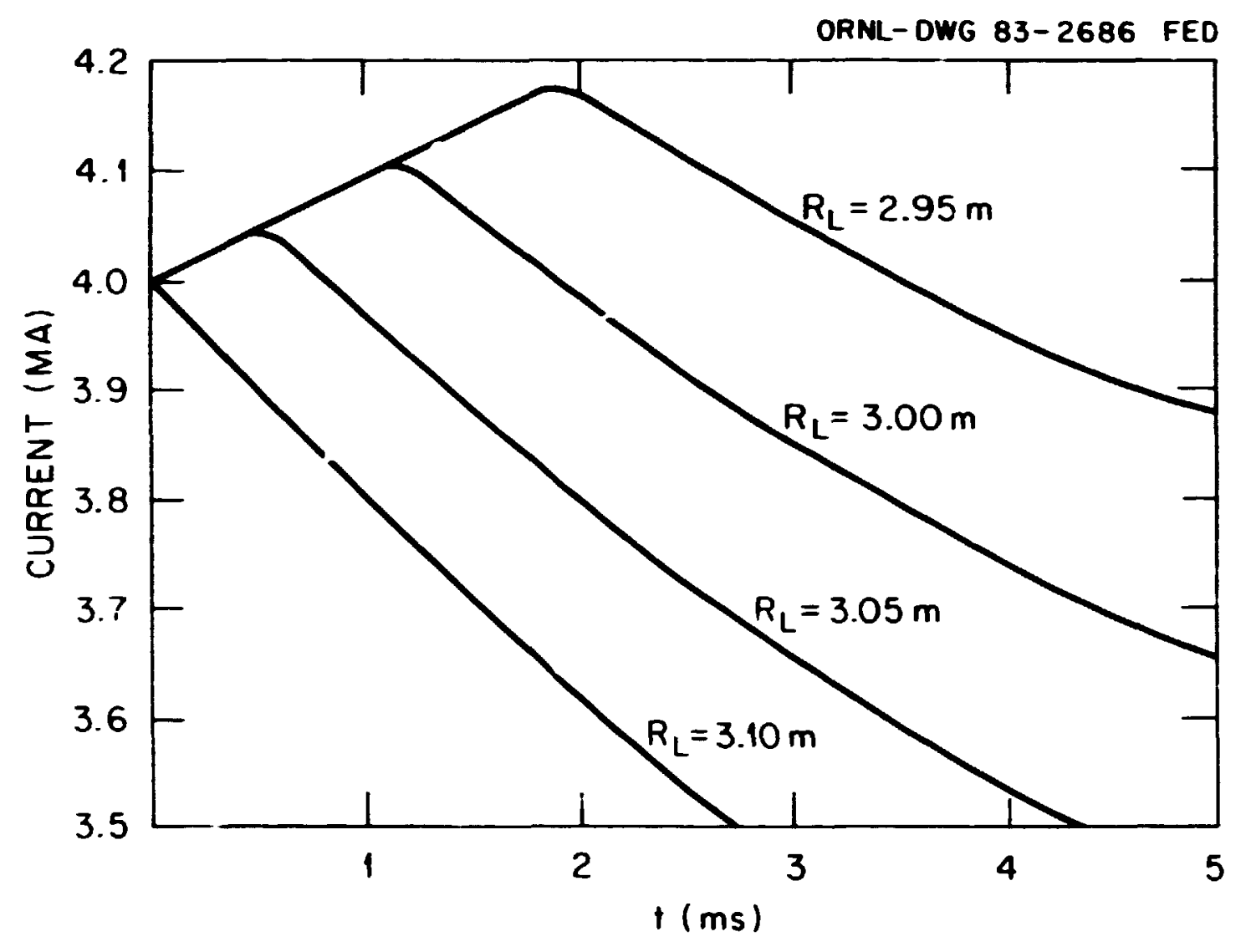

Fig. 5(a) 


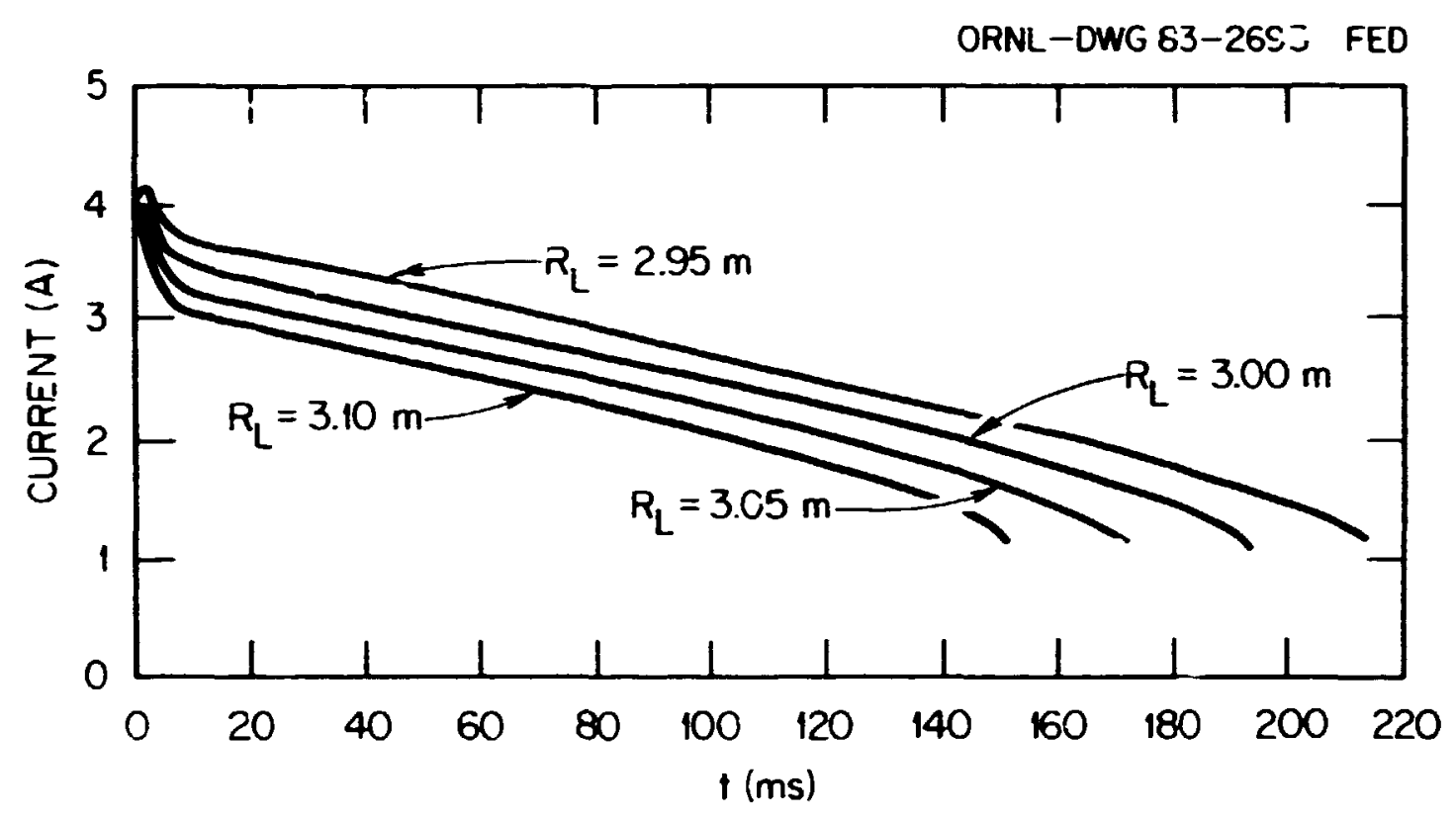

Fig. $5(b)$ 


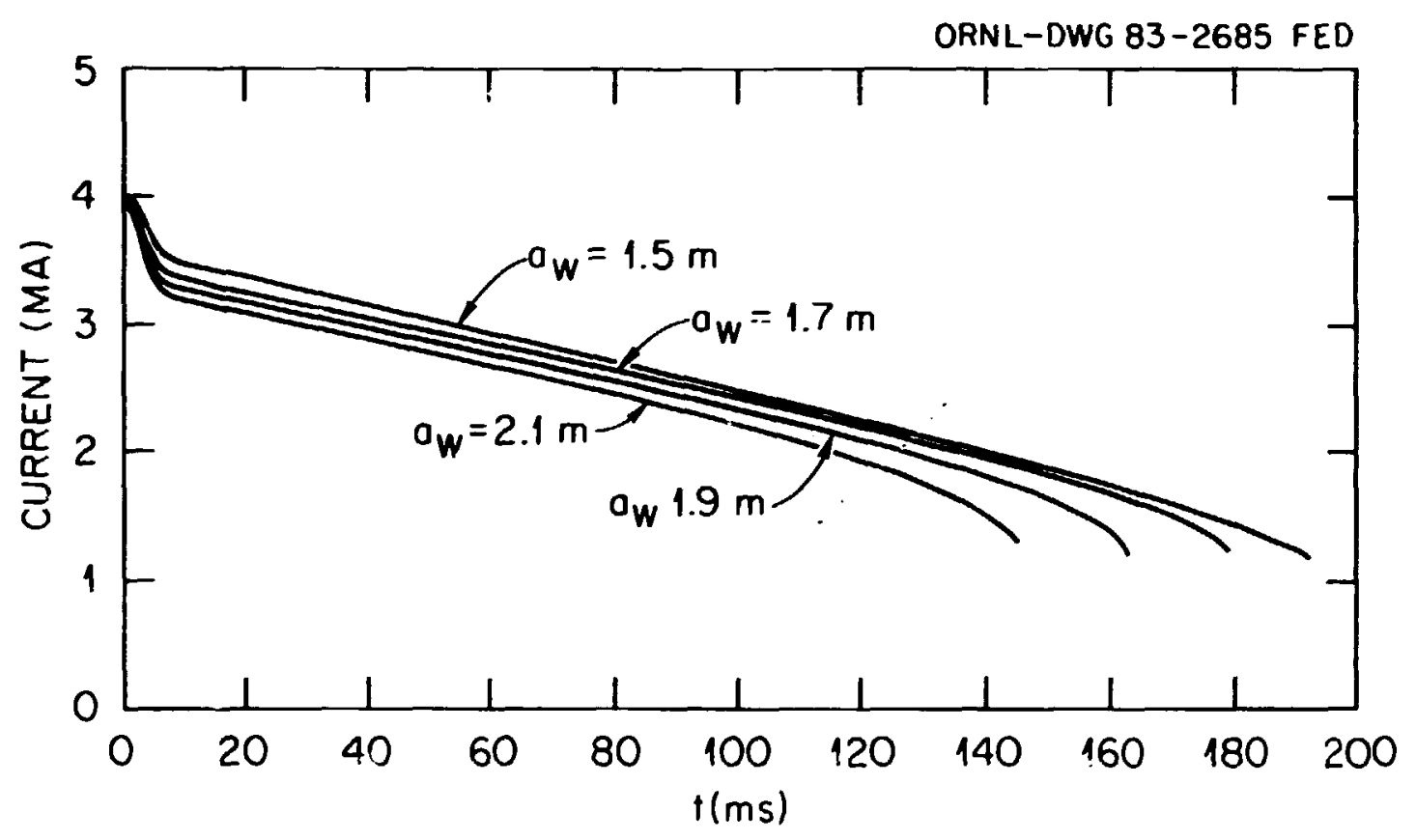

Fig. 6 
25

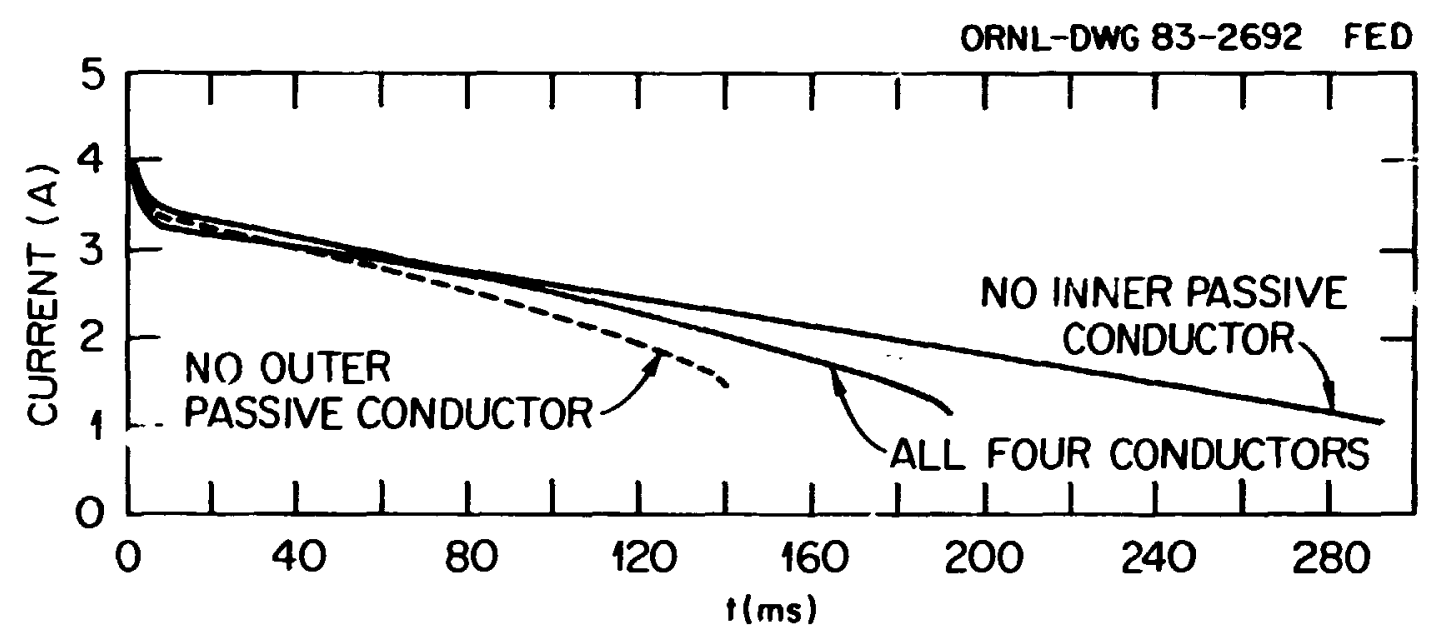

Fig. 7 

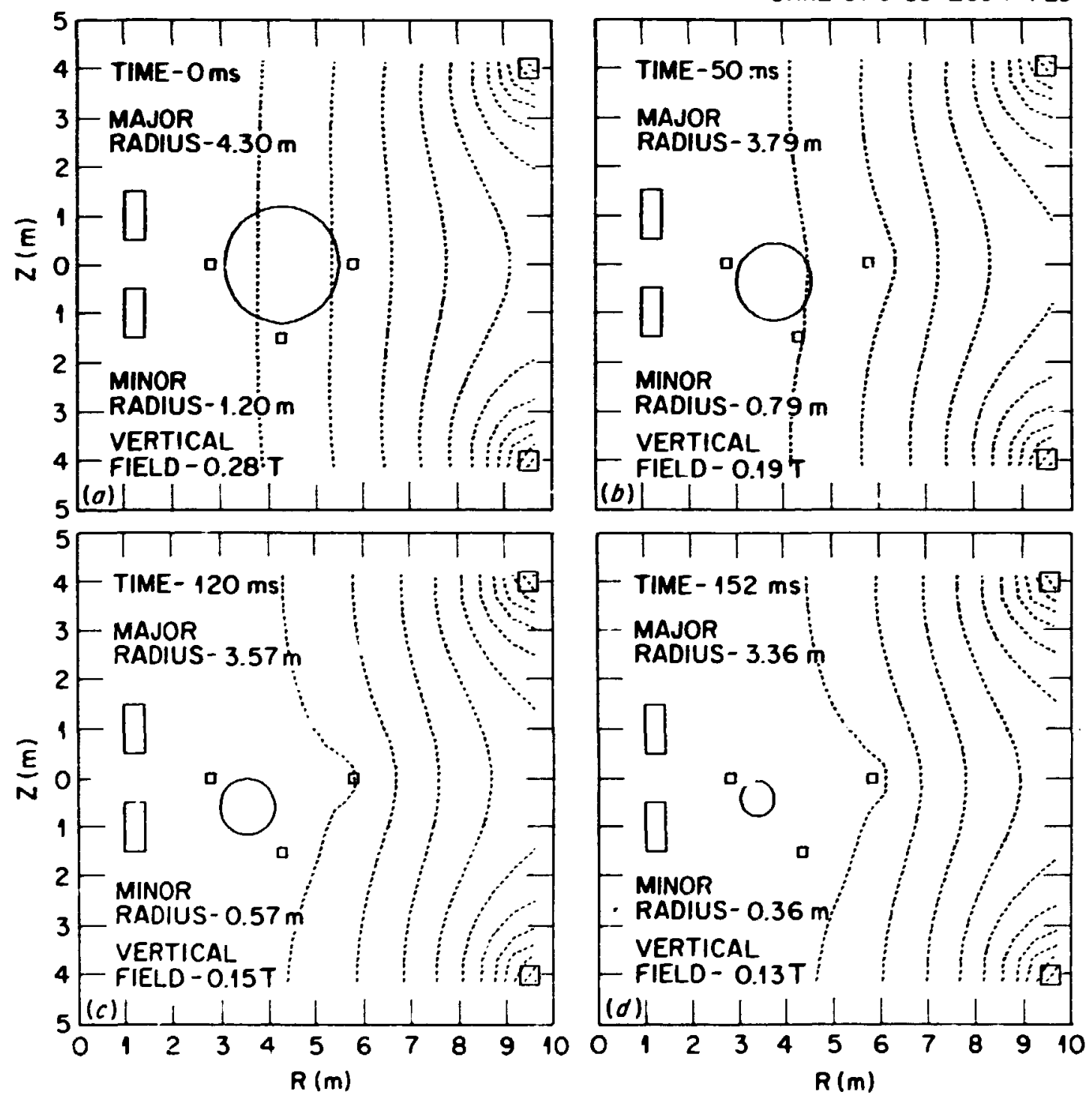

Fig. 8 
$27 / 28$

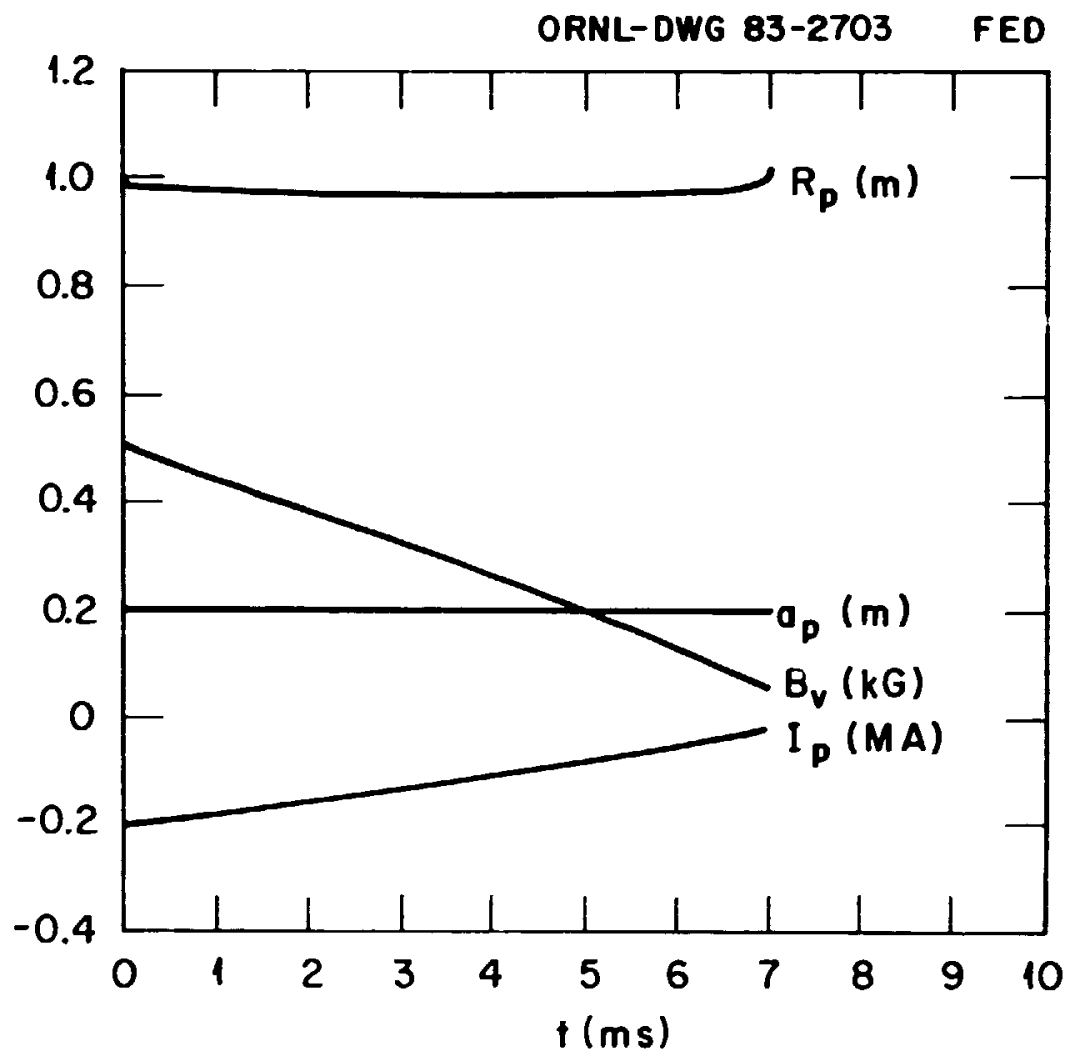

Fig. 9 
ORNL/FEDC- $\because 3 ! 2$

Dist. Category UC-2U c,d

\section{INTERNAL DISTRIBUTION}

1. S. K. Borowski

2. R. A. Dory

3. J. L. Dinlap

4. 0. C. Eldridge

5. C. A. Flanagan

6. J. C. Glowienka

7. G. E. Gorker

8. J. Haines

9. B. Carreras

10. L. M. Hively

11-15. J. A. Holmes

16. J. Kirchner

17-21. J. B. Miller

22. J. A. O'Toole

23-27. Y-K. M. Peng

28. R. L. Reid

\author{
29-33. K. E. Rothe \\ 34. :. J. Saltrarsh \\ 35. $\therefore$. E. Shannon \\ 36. J. Sheffield \\ 37-41. D. J. Strickler \\ 42. N. Uckan \\ 43. T. Uckan \\ 44-45. Laboratory Records Department \\ 46. Laboratory Records, ORNL-RC \\ 47. Document Reference Section \\ 48. Central Research Library \\ 49. Fusion Energy Division \\ Library \\ 50. Fusion Energy Division \\ Publications office \\ 51. ORNL Patent office
}

EXTERNAL DISTRIBUTION

52. M. A. Abciou, Associate Director, FPP/207, Argonne National Laboratory, 9700 South Cass Avenue, Argonne, Il 60439

53. N. A. Amherd, Fusion Power Program, Advanced Systems Department, Electric Power Rcsearch Institute, P.0. Box 10412, Palo Alto, CA 94304

54. J. L. Anderson, CMB-3, Mail Stop 348, Los Alamos National Laboratory, P.0. Box 1663, Los Alamos, NM 87545

55. M. Anderson, Tennessee Valley Authority, 1300 Commerce Bank Building, Chattanooga, TN 37401

56. 0. A. Anderson, Lawrence Berkeley Laboratory, University of California, Berkeley, CA 94720

57. D. J. Anthony, Advanced Power Program, Advanced Energy Programs Department, Building 2, Room 551, General Electric Company, Schenectady, NY 12345

58. C. C. Baker, FPP/208, Argonne National Laboratory, 9700 South Cass Avenue, Argonne, IL 60439

59. T. H. Batzer, L-536, Lawrence Lfvermore National Laboratory, P.O. Box 808, Livermore, CA 94550

60. J. E. Baublitz, of fice of Fusion Energy, Department of Energy, Washington, DC 20545

61. W. Bauer, Physical Research Division, Sandia National LaboratoriesLivermore, Livermore, CA 94550

62. J. F. Baur, GA Technologies, Inc., P.0. Box 81608, San Diego, CA 92138

63. D. S. Beard, Office cf Fusion Energy, Office of Energy Regearch, Mail Stop C,-256, U.S. Department of Energy, Washington, DC 20545 
64. R. J. Beeley, ETEC, Rockwell International, i.0. Box 144y, Canoga Park, CA 91304

65. D. C. Berkey, Vice President \& General Manager, Enezgy System and Technology Division, Gereral Electric Company, P.0. Box 7600, Stamford, CT 06904

66. K. L. Black, Depa: tment E45?, McDonnell Douglas Astronautics Company, P.o. Box 516, jt. Louis, Mo 63166

67. R. Botwin, C47-05, Gruwran Aerospace Corporation, P.0. Box 31, Bethpage, NY 11714

68. W. B. Briggs, MeDonnell Douglas Astronautics Company, P.0. Box 516, St. iouis, MO F 3166

69. G. Bronner, Princecon Plasma Physics Laboratory, P.0. Box 451, Princeton, NJ 08544

70. J. N. Brooks, FPP/207, Argonne National Laboratory, 9700 South Cass Avenue, Argonne, IL 60439

71. S. C. Burnett, GA Technologies, Inc., P.0. Box 81608, San Diego, CA 92138

72. J. D. Callen, Department of Nuclear Engineering, University of Wisconsin, Madison, WI 53706

73. V. S. Chan, GA Technologies, Inc., P.0. Box 81608, San Diego, CA 92138

74. R. G. Clemmer, Fusion Power Program, Argonne National Laboratory, 9700 South Cass Avenue, Argonne, IL 60439

75. D. R. Cohn, MIT Plasma Fusion Center, 167 Albany Street, Cambridre, MA 02139

76. N. S. Cooper, Lawrence Berkeley Laboratory, University of California, Berkeley, CA 94720

77. J. W. Coursen, C36-05, Grumman Aerospace Corporation, P.0. Box 31, Bethpage, NY 11714

78. R. W. Jonn, School of Chemical, Nuclear, and Thermal Engineering, Boelter Hall, University of California, Los Angeles, CA 90024

79. J. G. Crocker, EG\&G Idaho, P.0. Box 1625, Idaho Falls, ID 83401

80. A. E. Labiri, Energy Systems and Conservation Division, Science Applications, Inc., P.0. Box 2351, La Jolla, CA 92038

81. C. C. Damm, L-441, Lawrence Livermore National Laboratory, P. 0. Box 808 , Livermore, CA 94550

82. R. C. Davidson, Massachusetts Institute of Technology, 77 Massachusetts Avenue, Cambridge, MA 02139

83. N. A. Davies, Office of Fusion Energy, Office of Energy Research, Mail Station G-256, U.S. Department of Energy, Washington, DC 20545

84. J. W. Davis, E457, Building 81/1/B7, McDonnel1 Dnuglas Astronautics Company, P.0. Box 516, St. Louis, MO 63166

85. M. J. Davis, Sandia National Laboratorfes, P.0. Box 5800 , Aibuquerque, NM 87185

86. S. 0. Dean, Director, Fusion Energy Development, Science Applications, Inc., 2 Professional Drive, Sulte 249, Gaithersburg, MD 20760

87. J. F. Decke:, Office of Fusion Energy, Department of Energy, Mail Stop G-256, Washington, DC 20545

88. D. DeFreece, E451, Bullding 81/1/B7, McDonneli Douglas Astronautics Company, P.O. Box 5].6, St. Loufs, MO 63166 
89. A. Deitz, Princeton Plasma Physics Laboratory, P.0. Box 451, Princeton, NJ 08544

9C. D. A. Dingee, Program Manager, Fusion Technology, Pacific Northwest Laboratories, Battelle Boulevard, Richland, WA 99352

91. J. N. Doggett, L-441, Lawrence Livermore National Laboratory, P.0. Box 808, Livermore, CA 94550

92. H. Dreicer, Division Leader, CRT, Los Alamos National Laboratory, P.0. Bos. 1663, Los Alamos, NM 87545

93. D. Ehst, argonne National Laboratory, 9700 South Cass Avenue, Argonne, IL 60439

94. G. A. Eliseev, I. V. Kurchatov Irstitute of Atumic Energy, P.0. Box 3402, 123182 Moscow, U.S.S.R.

95. W. R. Ellis, Office of Fusion Energy, Department of Energy, Mail Stop G-256, Washington, DC 20545

96. B. A. Engholw, GA Techuologies, Inc., P.0. Box 81608, San Diego, CA 92138

97. H. P. Eubank, Princeton Plasma Physics Laboratory, P.0. Box 451, Princeton, NJ 08544

98. F. Farfaletti-Casali, Engireering Division, Joint Research Center, Ispra Establishment, 21020 Ispra (Varese), Italy

99. J. J. Ferrante, Manager, Building 36-241, Large Superconducting Program, General Electric Company, 1 River Road, Schenectady, NY 12345

100. J. File, Princeton Plasma Physics Laboratory, P.0. Box 451, Princeton, NJ 08544

101. P. A. Finn, Fusion Power Program, Argonne National Laboratory, 9700 South Cass Avenue, Argonne, IL 60439

102. H. K. Forsen, Bechtel Group, Inc., Research \& Engineering, P.0. Box 3965, San Francisco, CA 94119

103. J. S. Foster, Jr., Building R4-2004, TRW Defense and Space Systems, 1 Space Park, Redondo Beach, CA 90278

104. T. K. Fowler, Associate Director for MFE, L-436, Lawrence Livermore National Laboratory, P.0. Box 808, Livernore, CA 94550

105. J. W. French, EBASCO Services, Inc., Forrestal Campus, CN-59, Princeton University, Princeton, NJ 08544

106. H. P. Furth, Director, Prínceton Plasma Physics Laboratory, P.0. Box 451, Princeton, NJ 08544

107. J. G. Gavin, Jr., President, A01-11, Grumman Aerospace Corporation, P.0. Bnz 31, Bethpage, NY 11714

108. G. Gibson, Westinghouse Electric Corporation, Fusion Power Systems Department, P.0. Bo; 10864, Pittsburgh, PA 15236

109. J. R. Gilleland, Manager, Fusion Project, GA Technologies, Inc., P.0. Box 81608 , San Diego, CA 92138

110. V. A. Glukhikh, Scientific-Research Institute of Electro-Physical Apparatus, 188631 Leningrad, U.S.S.R.

111. M. Y. Gohar, Argonne National Laboratory, 9700 South Cass Avenue, Argonne, IL 60439

112. W. D. Goins, Tennessee Vajley Authority, 1300 Commerce Union Bank Buflding, Chat tanooga, in 37401

113. D. A. Coldberg, lawrence Berkeley Laboratory, University of Calffornia, Berkeley, CA 94720 
114. R. Goldston, Princeton Plasma Physics Laboratory, P.0. Box 451, Princeton, NJ 08544

115. M. B. Gottlieb, Princeton Plasma Physics Laboratory, P.0. Box 451, Princeton, NJ 08544

116. R. W. Gould, Department of Applied Physics, California Institute of Technology, Pasadena, CA 91109

117. M. W. Griffin, Department E236, McDonnell Douglas Astronautics Company, P.0. Box 516, St. Louis, MO 63166

118. C. R. Head, Office of Fusion Energy, Department of Energy, Mail Stop G-256, Washington, DC 20545

119. C. D. Henning, Lawrence Livermore National Laboratory, P.0. Box 80\&, Livermore, CA 94550

120. G. K. Hess, Office of Fusion Energy, Department of Energy, Mail St op ER-701, Washingion, DC 20545

121. T. Hiraoka, JT-60 Project Office I, Japan Atomic Energy Research Institnto, Tokai Research Establishment, Tokal, Ibaraki, Japan

122. R. L. Hirsch, Manager, Synthetic Fuels Research, Exxon Research and Engineering Company, P.0. Box 4255, Baytown, TX 77520

123. J. J. Holmes, Westinghouse-Hanford Engineering Development Laboratory, P.0. Box 1970, Richland, WA 99352

124. W. G. Homeyer, GA Technologies, Inc., P.0. Box 81608, San Diego, CA 92138

125. J. C. Hosea, Princeton Plasma Physics Laboratory, P.0. Box 451, Princeton, NJ 08544

126. D. Hwang, Princeton Plasma Physics Laboratory, P.0. Box 451, Princeton, NJ 08544

127. G. J. Inukai, Department E231, McDonnell Douglas Astronautics Company, P.0. Box 516, St. Louis, MO 63166

128. D. L. Jassby, Princeton Plasma Physics Laboratory, P.0. Box 451, Princeton, NJ 08544

129. J. B. Joyce, Prínceton Plasma Physics Latoratory, P.0. Box 451, Princeton, NJ 08544

130. R. A. Krakowski, CTR-12, Mail Stop 641, Los Alamos National Laboratory, P.0. Box 1663, Lus Alamos, NM 87545

131. G. L. Kulcinski, University of Wisconsin, Department of Nuclear Engineering, Engineering Research Building, Room 439, 1500 Johnson Drive, Madison, WI 53706

132. D. L. Kummer, McDonnell Douglas Astronautics Company, P.0. Box 516, St. Louis, MO 63166

133. T. S. Latham, Mail Stop 44, United Technologies Research Center, Silver Lane, East Hartford, CT 06108

134. L. K. Ledman, Of fice of Fusion Energy, Department of Energy, Mail Stop G-256, Washington, DC 20545

135. L. M. Lidsky, MIT Plasma Fusion Center, 167 Albany Street, Cambridge, MA 02139

136. C. S. Lfu, GA Technologies, Inc., P.O. Box 81608, San Diego, CA 92138

137. E. F. Lowell, General Manager, Energy Systems Programs Department, Building 2-455, General Electric Company, I River Road, Schenectady, NY 12345

138. D. J. McFarlin, Mail Stop 44, United Technologies Research Center, Silver Lane, East Hartford, CT 06108 
139. R. McGrath, Fusion Power Program, Argonne National Laboratory, 9700 South Cass Avenue, Argonne, IL 60439

140. V. A. Maroni, CEN/205, Argonne National Laboratory, 9700 South Cass Avenue, Argonne, IL 60439

i41. W. Marton, Office of Fusion Energy, Office or Energy Research, Mail Station G-256, U.S. Department of Energy, Washington, DC 20545

142. L. G. Masson, EG\&G Idaho, Idaho National Engineering Laboratory, P.0. Box 1625, Idaho Falls, ID 83401

143. D. G. McAlees, Exxon Nuclear Company, Inc., 777 106th Avenue, NE, Believue, WA 98009

144. D. M. Meade, Princeton Plasma Physics Laboratory, P.O. Boz 451, Princeton, NJ 08544

145. A. T. Mense, Building 107, Post B2, McDonnell Douglas Astronautics Company, P.0. Box 516, St. Louis, MO 63166

146. L. Michaels, Princeton Plasma Physics Laboratory, P.0. Box 451, Princeton, NJ 08544

147. D. Mikkelsen, Princeton Plasma Physics Laboratory, P.0. Box 451, Princeton, NJ 08544

148. R. L. Miller, GA Technologies, Inc., P.O. Box 81608, San Diego, CA 92138

149. R. G. Mills, Princeton Plasma Physics Laboratory, P.0. Box 451, Princeton, NJ 08544

150. J. I. D. Mitche11, Culham Laboratory, Abingdon, Oxon 0X14 3DB, Lnited Kingdon

151. R. W. Moir, Lawrence Livermore Natioral Laboratory, P.0. Box 808, Livermore, CA 94550

152. D. B. Montgomery, MIT Plasma Fusion Center, 167 Albany Street, Cambridge, MA 02139

153. K. Moses, R-1/1078, TKW Defense and Space Systems, 1 Space Park, Recondo Beach, CA 90278

154. R. E. Muller, Aerojet Manufacturing Company, P.0. Box 4210, Fullerton, CA 92934

155. A. F. Munier, Grumman Aerospace Company, P.0. Box 31, Bethpage, NY 11714

156. M. R. Murphy, Office of Fusion Energy, Department of Energy, Washington, DC 20545

157. R. E. Nygren, FPP/207, Argonne National Laboratory, 9700 South Cass Avenue, Argonne, IL 60439

158. T. Ohkakid, GA Technologies, Inc., P.0. Box 81608, San Diego, CA 92138

159. M. Okabayashi, Princeton Plasma Physics Laboratory, P.0. Box 451, Princeton, NJ 08544

160. i). Overskei, GA Technologies, Inc., P.0. Box 81608, San Diego, CA 92138

161. R. R. Parker, Francis Bitter National Magnet Laboratory, 170 Albany Street, Cambridge, MA 02139

162. B. Pease, Culham Laboratory, Abingdon, Oxon $0 \times 14$ 3DB, United Kingdom

163. M. Pelovilz, Princeton Plasma Physics laboratory, P.0. Box 451, Princeton, N.S 08544

164. F. W. Perkins, Princeton rlasma Physics laboratory, P.0. Box 451, Princeton, N.J 08544 
165. M. Petravic, Princeton Plasma Physics Laboratory, P.0. Box 451, Princeton, NJ 08544

i66. M. Porkolab, Massachusetts Institute of Technology, 77 Massachusetts Avenue, Cambridge, MA 02139

167. D. E. Post, Princeton Plasma Physics Laboratory, P.o. Box 451, Princeton, NJ 08544

168. L. K. Price, Department of Energy, Oak Ridge Operaiions, P.0. Box E, Oak Ridge, TN 37830

169. R. E. Price, Office of Fusion Energy, Office of Energy Research, Mail Station G-256, Washington, DC 20545

170. D. H. Priester, Of fice of Fusion Energy, Department of Energy, Washington, DC 20545

171. F. A. Puhn, GA Technologies, Inc., P.0. Box 81608, San Diego, CA 92138

172. J. Purcell, GA Technologies, Inc., P.0. Box 81608, San Tiego, CA 92138

173. R. V. Pyle, University of California, Lawrence Berkeley Laboratory, Berkeley, CA 94720

174. J. M. Rawls, GA Technologies, Inc., P.0. Box 81608, San Diego, CA 92138

175. P. J. Reardon, Princeton Plasma Physics Laboratory, P.0. Box 451, Princeton, NJ 08544

176. M. Roberts, Office of Fusion Energy, Department of Energy, Mail Stop C-256, Washington, DC 20545

177. J. D. Rogers, Los Alamos National Laboratory, P.0. Box 1663, Los Alamos, NM 87545

178. F. L. Robinson, Tennessee Valley Authority, 1300 Commerce Bank Building, Chattanooga, IN 37401

179. M. I.. Rogers, Monsanto Research Corporation, Mound Laboratory Facility, P.0. Box 32, Miamisburg, OH 45342

180. M. N. Rosenbluth, RLM 11.218, Institute for Fusion Studies, University of Texas, Austin, TX 78712

181. L. Ruby, Lawrence Berkeley Laboratory, University of California, Berkeley, CA 94720

182. P. H. Rutherford, Princeton Plasma Physics Laboratory, P.0. Box 451, Princeton, NJ 08544

183. D. D. Ryutov, Institute of Nuclear Physics, Siberian Branch of the Academy of Sciences of the U.S.S.R., Sovetskaya St. 5, 630090 Novosibirsk, U.S.S.R.

184. M. M. Sabado, EB:SCo Services, Inc., A Site, Bullding 1-A, Forrestal Campus, Princeton, NJ 08544

185. J. A. Schmidt, Princeton Plasma Physics Laboratory, P.0. Box 451, Princeton, NJ 08544

186. J. Schultz, MIT Plasma Fusion Center, 167 Albany Street, Cambridge, MA 02139

187. F. R. Scott, Electric Power Research Institute, P.U. Box 10412, Palo Alto, CA 94304

188. G. Sheffield, Princeton Plasma Physics Laboratory, P.0. Box 451 , Princeton, NJ 08544

189. C. E. Singer, Princeton Plasma Physics Laboratory, P.0. Box 451, Princeton, NJ 08544 
190. T. J. M. Sluyters, Accelerator Department, Brookhaven Mational Laboratory, Upton, NY 11973

191. D. Smith, Materials Science Division, Argome Mational Laboratory, 9700 South Cass Avenue, Argonne, IL 60439

192. G. E. Smith, Gruman Aerospace Corporation, P.0. Box 31, Bethpage, NY 11714

193. R. I. Smith, Board Chairman, Public Service Electric and Gas Company, 80 Park Place, Newark, MJ 07101

194. L. Soroka, Lawrence Berkeley Laboratory, University of California, Berkeley, CA 94720

195. L. Southworth, GA Technologies, Inc., P.0. Box 81608, San Diego, CA 92138

196. I. Spighel, Lebedev Physical Institute, Leninsky Prospect 53, 117924 Hoscow, U.S.S.R.

197. H. M. Stacey, Jr., Georgia Institute of Technology, School of Nuclear Engineering, At lanta, GA 30332

198. E. Stern, Gruman Aerospace Corporation, CN-59, Forrestal Campus, Princeton, NJ 08544

199. L. D. Stewart, Princeton Plasua Physics Laboratory, P.0. Box 451, Princeton, NJ 08544

200. H. Stodiek, Princeton Plasaa Physics Laboratory, P.0. Box 451, Princeton, NJ 08544

201. P. M. Stone, Office of Fusion Energy, Office of Energy Research, Mail Station G-256, Washington, DC 20545

202. I. N. Sviatoslavsky, Room 33, Engineering Research Building, 1500 Johnson Drive, University of Wisconsin, Madison, WI 53706

203. T. Tamano, GA Technologies, Inc., P.0. Br,x 81608, San Diego, CA 92138

204. R. E. Tatro, Manager, Energy Systems, M.2. 16-1070, General DynamicsConvair Division, P.0. Box 80847, San Diego, CA 92138

205. F. Tenney, Princeton Plasma Physics Laboratory, P.0. dox 451, Princeton, NJ 08544

206. F. Tilomas, B-20-5, Grumman Aerospace Corporation, Bethpage, NY 11714

207. K. 1. Thomzssen, Lawrence Lfvermore National Laboratory, P.0. Box 808, Livermore, CA 94550

208. R. J. Thome, Francis Bitter National Magnet Laboratory, 170 Albany Street, Cambridge, MA 02139

209. S. L. Thomson, Bechtel Group, Inc., P.0. Box 3965, San Francisco, CA 94119

210. V. T. Tolok, Kharkov Physical-Technical Institute, Academical St. 1, 310108 Kharkov, U.S.S.R.

211. C. Trachsel, McDonnel1 Douglas Astronautfcs Company, P.0. Box 516, St. Louis, MO 63166

212. J. R. Treglio, General Dynamics-Convair Division, P.0. Br,x 80847, San Diego, CA 92138

213. A. W. Trivelpiece, Office of Energy Research, Department of Energy, Washington, DC 20545

214. L. R. Turner, Fusion Power Program, Argonne National Laboratory, 9700 South Cass Avenue, Argonne, Il 60439 
215. M. A. Ulrickson, Princeton Plasea Physics Laboratory, P.0. Box 451, Princeton, NJ 08544

216. E. H. Valeo, Princeton Plasma Physics Laboratory, P.0. Box 451 , Princeton, NJ 08544

217. T. C. Varljen, Westinghouse Electric Corporation, P.0. Box 10864, Pittsburgh, PA 15236

218. R. Varma, Physical Research Laboratory, Mavangpura, Ahwedabad, India

219. H. F. Voge1, Los Alamos National Laboratory, P.0. Box 1663, Los Alamos, MH 87545

220. A. Wait, Building 36-421, General Electric Company, 1 River Road, Schenectady, NY 12345

221. K. E. Wakefield, Princeton Plasma Physics Laboratory, P.0. Box 451, Princeton, NJ 08544

222. N. Weldon, Los Alamos National Laboratory, P.0. Box 1663, Los Alamos, NA 87545

223. J. C. Wesley, GA Technologies, Inc., P.0. Box 81608, San Diego, CA 92138

224. S. Whitley, Tennessee Valley Authority, 1300 Cownerce Bank Building, Chat tanooga, TN 37401

225. W. R. Hilkes, Monsanto Research Corporation, Mound Laboratory Facility, P.0. Box 32, Miamisburg, Ot 45342

226. J. E. Hilkins, EG\&G Idaho, Idaho Natioral Engineering Laboratory, P.0. Box 1625, Idaho Falls, ID 83401

227. H. Willenberg, Mathematical Sciences Northwest, Inc., P.0. Box 1887, Bellevue, NA 98009

228. J. E. C. Willians, Francis Bitter National Magnet Laboratory, 170 Albanj Street, Cambridje, MA 02139

229. P. Willis, Building 23, Room 298, General Electric Company, 1 River Road, Schenectady, NY 12345

230. T. F. Yang, MIT Plasma Fusion Center, 167 Albany Street, Cambridge, MA 02139

231. H. H. Yoshikawa, W/A-62, Hanford Engineering Development Laboratory, P.O. Box 1970, Richland, WA 99352

232. K. M. Young, Princeton Plasma Physics Laboratory, P.0. Box 451, Princeton, NJ 08544

233. N. E. Young, EBASCO Services, Inc., Princeton Plasma Physics Laboratory, P.0. Box 451, Princeton, NJ 08544

234. K. M. Zwilsky, National Materials Advisory Board, National Academy of Sciences, 2101 Constitution Avenue NW, Washington, DC 20418

235. Bibliothek, Max-Planck Institut fur Plasmaphysik, D-8046 Garching bei Munchen, Federal Republic of Germany

236. Bfbliothek, Institut fur Plasmaphysik, KFA, Postfach 1913, D-5170 Julich, Federal Republic of Germany

237. Bibliotheque, Centre de Recherches en Physique des Plasmas, 21 Avenue des Bains, 1007 Lausanne, Switzerland

238. Bibliotheque, Service du Confinement des Plasmas, CEA, B.P. No. 6, 92 Fontenay-aux-Roses (Seine), France

239. Documentation S.I.C.N., Department de la Physique du Plasma et de la Fusion Controlee, Association EURATOM-CEA, Centre d'Etudes Nuclcatres, B.P. 85, Cencre du Tr1, 38041 Grenoble, Cedex, France 
240. Library, Centre de Recherches en Physique des Plasmas, 2I Avenue des Bains, 1007 Lausanne, Switzerland

241. Library, Culham Laboratory, UKAliA, Abingdon, Oxon, Ox14 3DB, England

242. Library, FOA Institut voor Plasma-Fysica, Rijnhuizen, Jutphaas, Netherlands

243. Library, Institute of Piysics, ticademia Sinica, Beijing, Peoples Republic of China

244. Library, Institute for Plasma Physics, Nagoya University, Nagoya 464, Japan

245. Library, International Centre for Theoretical Physics, Trieste, Italy

246. Library, JET Joint Undertaking, Abingdon, Oxfordshire, OX14, DB, England

247. Library, Laboratoria Gas Ionizzati, Frascati, Italy

248. Plasma Research Laboratory, Australian National University, P.0. Box 4, Canberra, ACT 2000, Australia

249. Thermonuclear Library, Japan Atowic Energy Researrh Institute, Tokai, Naka, Ibaraki, Japan

250. Library, Plasma Physics Laboratory, Kyoto University, Gokasho Uji, Kyoto, Japan

251. Office of the Assistant Manager for Energy Research and Development, Department of Energy, Oak Ridge Operations, Oak Ridge, TN 37830

252-455. Given distribution as shown in TID-4500, Magnetic Fusion Energy, (Distribution Category UC-20 c,d: Reactor Materials and Fusion Systems) 